\title{
Article
}

\section{A Positive, Communitarian Right to Security in the Age of Super-Terrorism}

\author{
Turner, Ian David \\ Available at http://clok.uclan.ac.uk/15660/ \\ Turner, Ian David ORCID: 0000-0002-8012-1480 (2016) A Positive, \\ Communitarian Right to Security in the Age of Super-Terrorism. Democracy \\ and Security, 13 (1). pp. 46-70. ISSN 1741-9166
}

It is advisable to refer to the publisher's version if you intend to cite from the work. http://dx.doi.org/10.1080/17419166.2016.1242420

For more information about UCLan's research in this area go to http://www.uclan.ac.uk/researchgroups/ and search for < name of research Group>.

For information about Research generally at UCLan please go to http://www.uclan.ac.uk/research/

All outputs in CLoK are protected by Intellectual Property Rights law, including Copyright law. Copyright, IPR and Moral Rights for the works on this site are retained by the individual authors and/or other copyright owners. Terms and conditions for use of this material are defined in the policies page.

\section{CLoK}

Central Lancashire online Knowledge www.clok.uclan.ac.uk

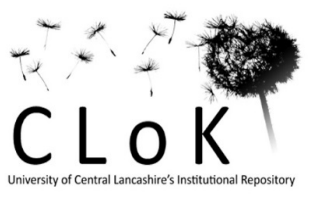




\title{
A 'Positive', 'Communitarian' Right to Security in the Age of 'Super-Terrorism'
}

\author{
Ian Turner*
}

\section{Abstract}

Post 9/11, and especially with the dramatic rise of Islamic State in Iraq and the Levant (ISIL), the author advocates a collective right to security. Plotting a course through state absolutism and liberalism one 'finds' communitarianism as a philosophy to support this right to security. The author's 'communitarian', right to security is based on an interpretation of European human rights law, particularly 'positive' duties of the state, to protect the rights to life of individuals from violations by non-state actors such as suspected terrorists. But for reasons of practical enforcement limitations to the exercise of the right are also articulated.

\section{Keywords}

Human rights; positive obligations; right to security; communitarianism

\section{Introduction}

Post 9/11 the threat to the UK from Islamist terror groups such as Al-Qaeda has continued: there was the 'Ricin case', a plot to spread deadly ricin across London, in 2003; and the '7/7' suicide attacks on the London transport network, as well as four 
failed suicide bombings two weeks later, in 2005. There was also the 'Airline Bomb Plot', a plot to detonate homemade explosives on airliners mid-flight over the Atlantic Ocean, in 2006; car bomb attacks in London and Glasgow in 2007; a failed suicide bombing in Exeter in 2008; the discovery of an explosive device on a cargo plane at East Midlands airport in 2010; the convictions of eight men conspiring to detonate suicide vests across various parts of the UK in 2012; and the murder of a soldier, Lee Rigby, in a London street in 2013. Whilst the threat to the UK's security from Al-Qaeda in Afghanistan and Pakistan has decreased, with the killing of Osama Bin Laden by American Special Forces in May 2011, for example, acts of 'super-terrorism' ${ }^{1}$ by other Islamist groups have not abated. In particular, there has been the spectacular rise of Islamic State of Iraq and the Levant (ISIL), over the last few years with its beheadings of Westerners, such as James Foley, for example, videos of which were posted on the internet. Indeed, the murder of James Foley caused the UK government to increase its terror threat level from 'substantial' to 'severe' in August 2014. The UK's terror threat level remains at 'severe', meaning an attack is 'highly likely', at least two years later. More recently, ISIL has been responsible for targeting primarily close allies of the UK: its shootings at the Jewish Museum in Brussels, Belgium, in May 2014; the offices of the satirical magazine, Charlie Hebdo, in Paris, France, in January 2015; and a café and a synagogue in Copenhagen, Denmark, in February 2015. Lately, ISIL committed a massacre in Paris, primarily at the Bataclan Theatre, where 89 people were killed, in November 2015, and was responsible for two suicide bombings in Brussels at the airport and a train station, killing 31 people, in March 2016. According to the latest Global Terrorism Index, 2015, however, $78 \%$ of all deaths and 57\% of all attacks in 2014 occurred in just five countries: Afghanistan, Iraq, Nigeria, Pakistan and Syria ${ }^{2}$. Indeed, excluding the $9 / 11$ attacks, only $0.5 \%$ of deaths 
from terrorism have occurred in the West since $2000 .^{3}$ Thus, notwithstanding the continuous Islamist terror threats to the UK and its close allies since $9 / 11$, these countries in the West are relatively safe. This is not to ignore ongoing threats to their collective security, however. Indeed, senior police officers across Europe now claim that the continent faces its highest terror threat since $9 / 11 .{ }^{4}$

The threat to international peace and security from ISIL has been a cause of concern for the international community such as the United Nations (UN) for some time. Recently, the UN Security Council adopted a resolution, 2249 (2015), calling upon all Member States of the UN to take all necessary measures to prevent and suppress terrorist acts committed specifically by ISIL. States therefore need to remain strong and vigilant if they are to be successful in preventing, or at least reducing, Islamist terrorism from groups such as ISIL. Contributing to the debate about states' need to provide effective protection to their citizens, this article supports a human right to security in the UK - but not the furtherance of the conventional, 'negative', right to security of the individual from the state: a 'positive', 'communitarian' right of security from threats to public safety from non-state actors such as suspected terrorists derived from European human rights law.

Ordinarily, human rights act 'negatively', in that they reflect a traditional, liberal desire to restrain curtailments of individual freedom by the state; they are 'freedoms from' governmental intrusion. Article 3 of the European Convention on Human Rights (ECHR), for example, is the 'freedom from' torture. But the right also acts 'positively', in that it obliges countries to prevent violations of the freedom by non-state actors such as 
suspected terrorists. A basis, therefore, for the author's human right to security in the UK are the 'positive' obligations imposed on European states to, say, protect life, as per Article 2(1) of the ECHR, and prevent injury, as per Article 3 of the ECHR. (The author confines his approach primarily to the UK because European human rights law is directly applicable in the country's domestic law, as per the Human Rights Act 1998, though the principles that European Human Rights Law articulates could easily translate to other states in the region, and elsewhere.) In addition, the author marries these 'positive' obligations with the philosophies of, say, communitarianism, to supply a theoretical base to his right of security. But before doing so, he discusses the 'right to security' - or at least refers to its many interpretations.

\section{Defining a right to security}

Surprisingly, explaining a right to security is not easy. Powell, for example, has expressed concern at the failure of human rights law to define exactly what the concept of security is: it is merely assumed that security is clearly understood and can be taken for granted. ${ }^{5}$ In simple terms, Hein van Kempen says that security is described as freedom from threat, danger, vulnerability, menace, force and attack. ${ }^{6}$ But the 'rather basic nature of this definition' should not disguise the fact that there are many different forms of security, and that the meaning is both developing and highly contested. ${ }^{7}$ The following sub-sections explore the many approaches to security. 


\section{Negative individual security against the state}

The right to security is an example of a 'First Generation', 'civil and political', 'negative' right; a 'freedom from' state intrusion. ('First Generation' rights protect individuals from 'arbitrary' killing, torture, slavery etc by the state.) The 'substantive' right to security of the individual from the power of the state - distinguishing it from, say, its 'procedural' element ${ }^{8}$ - is expressly provided for by several international and regional human rights documents. For example, Article 9(1) of the International Covenant on Civil and Political Rights (ICCPR) states: 'Everyone has the right to liberty and security of person. ${ }^{9}$ Article 5(1) of the ECHR is expressed in similar terms. Several human rights commentators examine only the 'liberty' element of Article 5(1) of the ECHR, paying no regard at all to 'security'. ${ }^{10}$ But the European Court of Human Rights (ECtHR) in East African Asians v. United Kingdom ${ }^{11}$ suggested the terms were synonymous: 'the protection of 'security'...is concerned with arbitrary interference, by a public authority, with an individual's personal 'liberty'. ${ }^{12}$

\section{Security as justification to limit human rights}

Many individual human rights, whether they be guaranteed by international, regional and/or domestic instruments, are 'qualified', in that they can be infringed by the state for legitimate purposes, one of which is safeguarding security. Article 19(2) of the ICCPR states: 'Everyone shall have the right to freedom of expression...' But according to Article 19(3) there are express limits to this freedom: 'The exercise of the rights provided for in paragraph 2 carries with it special duties and responsibilities. It may therefore be subject 
to certain restrictions...(b) For the protection of national security or of public order...' Regionally, Article $10(1)$ of the ECHR is the right to freedom of expression. But it is qualified, too, by Article 10(2), in the interests of national security, territorial integrity or public safety, for the prevention of disorder or crime etc assuming such interferences are 'necessary in a democratic society'. In addition to such 'qualifications' of general applicability, human rights law also provides for 'derogations', suspending specified freedoms in, say, times of 'public emergency threatening the life of the nation'. Article $4(1)$ of the ICCPR, for example, permits derogations in such circumstances 'to the extent strictly required by the exigencies of the situation, ${ }^{13}$ as does Article $15(1)$ of the ECHR.

\section{Positive individual security against the state}

Under human rights law an individual's right to security can also be interpreted as an example of a 'Second Generation', 'economic, social and cultural', 'positive' right of the individual; a 'right to'. For example, Article 9 of the International Covenant on Economic, Social and Cultural Rights (ICESCR) states: 'The States Parties to the present Covenant recognize the right of everyone to social security, including social insurance.' ${ }^{14}$

\section{International or collective security}

The right to security also extends to a 'Third Generation', 'collective' right of peoples and groups of individuals. For example, Article 23(1) of the African Charter on Human and Peoples' Rights (ACHPR) states: 'All peoples shall have the right to national and international peace and security.' The Charter of the United Nations (UN) recognises 
collective rights to security, too: one of the purposes of the UN, as per Article $1(1)$, is 'to maintain international peace and security...' Moreover, Article 2 of the Charter obliges UN members to 'settle their international disputes by peaceful means in such a manner that international peace and security, and justice, are not endangered' and must 'refrain in their international relations from the threat or use of force against the territorial integrity or political independence of any state...'15 International security is also maintained by the four Geneva Conventions, 1949. Geneva IV, for example, protects civilians in armed conflicts. This principle is extended by the Conventions' First and Second Protocols, $1977 .^{16}$

Within international security there is collective - or human - security. ${ }^{17}$ 'Human security' was one of a number of international principles agreed at the World Summit in 2005. These were subsequently adopted by a resolution of the High Level Plenary Meeting of the UN General Assembly in September $2005 .{ }^{18}$ There is no real consensus as to what human security exactly means, however. ${ }^{19}$ That said, there is a protection-based approach to human security, which focuses its attention on 'freedom from fear'.$^{20}$ It was this conception of human security which provided a theoretical foundation for the development of the 'responsibility to protect ('R2P') concept to protect civilian populations from genocide, war crimes, ethnic cleansing and crimes against humanity. ${ }^{21}$ ' $\mathrm{R} 2 \mathrm{P}^{\prime}$ was another principle endorsed at the UN World Summit in $2005 .{ }^{22}$ Of note is paragraph 138 of the resolution adopted by the High Level Plenary Meeting of the UN General Assembly in 2005. This imposes not only obligations on countries to protect their civilians ('Pillar I'), but also duties upon the international community to help states meet those obligations ('Pillar II'). If a state has 'manifestly failed' in its duty to protect, 
then paragraph 139 of the resolution refers to obligations to take concrete and collective interventionist measures on a case by case basis ('Pillar III').

The central tenet of ' $\mathrm{R} 2 \mathrm{P}$ ' is that state sovereignty entails responsibilities as well as physical and political jurisdiction. The state may have the right to manage affairs within its borders, but it also has the fundamental responsibility of shielding populations within those borders from the four crimes outlined above. ${ }^{23}$ This principle, therefore, affirms an obligation on states not to remain neutral in the face of, say, genocide. Thus ' $R 2 \mathrm{P}^{\prime}$ applies even where the harm has been inflicted by third parties such as armed rebel groups. Such a 'positive' or 'substantive' duty, enforceable against non-state actors, is well developed in human rights law, particularly in Europe. This obligation forms a foundation for the author's right to security outlined in this piece.

\section{Positive state obligation to offer security to individuals against other individuals}

The final security concept, therefore, requires states to take 'positive' measures to prevent harms committed by third parties. In protecting individuals from violations of rights by non-state actors - killing, torture, enforced disappearance, slavery, for example - states, on a general level, must criminalise such abuses and to actively take measures to investigate, prosecute, convict and adequately punish those found to be responsible such violations. At an international level it will recalled that Article 9(1) of the ICCPR asserts a right to liberty and security of person. The distinctly 'negative' element of the right - that is, 'freedom from' state intrusion - was discussed above. However, the key point here is that this freedom also imposes a 'positive' duty on the state to formulate 
policies and take concrete measures preventing infringements of the right by third parties. The UN Human Rights Committee (HRC) monitors states' compliance of the ICCPR. In Jayawardena v. Sri Lanka, ${ }^{24}$ for example, the claimant alleged an infringement of his right to security, after the President of Sri Lanka had accused him in public of being involved with the terror group, the Liberation Tigers of Tamil Elam ('LTTE'), putting his life at risk. The HRC found that these accusations by the President had caused the claimant to be a victim of threats to his security by third parties, in violation of Article $9(1) \cdot{ }^{25}$

Regionally, the concept of 'positive' obligations seems to be most developed in the case law of the ECHR, such as Article 3, freedom from torture and inhuman and degrading treatment and punishment; ${ }^{26}$ Article 4(1), freedom from slavery and servitude, ${ }^{27}$ including human trafficking; ${ }^{28}$ Article 5 , the right to liberty and security of person; ${ }^{29}$ and Article 8 , the right to private and family life, home and correspondence. ${ }^{30}$ Pointedly, therefore, despite the ECHR's general reiteration of 'freedoms from' the state, in many instances the European Court of Human Rights (ECtHR) has drawn 'positive' obligations from the text of the 'negative' right itself. And the ECHR expresses positive obligations in discrete terms; for instance, Article 2(1) of the ECHR states that everyone's right to life shall be protected by law. ${ }^{31}$ Similarly, Article 6 confers a right on individuals to receive a 'fair trial' by an independent and impartial court or tribunal, which requires states, therefore, to publicly fund and staff an independent and adequate legal system that is fit for purpose. 
Individual protections aside, the ECHR also imposes a 'positive' duty on member states to respect human rights in general. Indeed, the full title of the ECHR is the 'Convention for the Protection of Human Rights and Fundamental Freedoms'. ${ }^{32}$ Article 13 of the $E C H R$, for example, also requires states to take measures guaranteeing an effective remedy where there has been a violation of a right. ${ }^{33}$ And of particular significance for the meaning and scope of a right to security there is Article 1 of the ECHR: 'The High Contracting Parties shall secure to everyone within their jurisdiction the rights and freedoms defined in Section I of this Convention [my italics].' Interestingly, therefore, we can question why security is specifically referred to in Article $5(1)$ of the ECHR? ${ }^{34}$ This does not imply that Article 5 is an 'exception' reflecting the lower status afforded to security. Instead, Article 1 affirms the centrality of security built into each of the ECHR rights rendering reference to it in any particular right, such as Article 5, arguably redundant.

This author has identified many approaches to security as a human right, encompassing both 'negative' as well as 'positive' elements, but there is a tendency to see the right primarily in 'First Generation' terms; and within this, 'liberty' and 'security' seemingly represent the same freedom. Lazarus is perplexed, however. She states that national security policy, say, since the 9/11 attacks in New York and Washington in 2001, has overwhelmingly focused on the 'balance' between 'security' on the one hand and 'liberty' on the other. Given that liberty and security are articulated as part of the same right in most human rights documents, she suggests that this 'binary opposition...is curious'.$^{35}$ She concludes: amidst the extensive public debate on the appropriate balance between the maintenance of national, public and individual security on the one hand, 
and the protection of individual liberty on the other, 'remarkably little attention has been paid to the question of what precisely is meant by the right to security in the legal sense' ${ }^{36}$ The implication of the argument here is that a human right to security, in law, could therefore be said to be 'up for grabs'. This piece is (hopefully) a pitch for a specific interpretation of security.

'Super terror' attacks by ISIL, for example, show no sign of decreasing. Indeed, discussing the level of threat to the UK from Islamist terrorism, Andrew Parker, the Director General of Britain's Security Service ('MI5'), recently noted: 'We face a very serious threat that is complex to combat and unlikely to abate significantly for some time..37 With the ongoing threat to the UK and its allies from Islamist terror groups, human rights law, particularly in the European region, is especially relevant. Perhaps the UK's positive duty to prevent harm committed by third parties - drawing on the jurisprudence of the ECtHR, as well as specific articles of the ECHR such as Arts 1, 2 and 13 - can form the basis for a right to security from ISIL? A collective human right to security (though not in the sense as understood in international law - see above)? Of course human rights are traditionally seen as 'freedoms from' governmental abuse. But this piece has shown that a right to security has many approaches beyond the natural defence of the individual against arbitrary detention by the state. Many traditionalists will reject the approach to human rights articulated here as merely provocative and, therefore, insufficiently worthy of academic debate. But the author believes it is important to have this discussion. In law, for example, 'freedom from torture, such as Article 3 of the ECHR, is 'absolute' meaning it can never be infringed. Indeed, it cannot be suspended in times of war or public emergency, as per Article 15(2) of the ECHR. Is it wrong to debate the 
absolute nature of 'torture', particularly, in the context of terrorism? In a special issue of the European Human Rights Law Review debating torture, the editor rejected claims that academic discussions about the nature of the right undermined its absoluteness:

'[I]f torture were not a legitimate topic for debate, it would never have been prohibited in the first place and the fact of its being prohibited as a matter of international law cannot and should not preclude its discussion: on the contrary, it demands it. It is a lack of debate which would be more worrisome since this would threaten to condemn the prohibition to obscurity. ${ }^{38}$

Thus, in having the debate about a positive, collective right to security, the consequence of which is naturally an augmentation of state power, this piece will also serve as an important reminder of the historical significance of human rights of the individual, even it if its ultimate aim post $9 / 11$ is perhaps to challenge it! Indeed, in calling on the international community to take all necessary measures to prevent and suppress terrorist acts committed specifically by ISIL, as per UN Security Council Resolution 2249 (2015) (see above), notably, this duty is not without limitation: it is prefaced by states' human rights obligations, for example. Crudely, states are seeking to prevent terrorism, not introduce measures that are counter-productive because of the undermining of basic freedoms. It is hoped that this important consideration is not lost here. In the next section, the author seeks to provide a philosophical base for the approach to security he advocates in this work. 


\section{Theoretical justifications for the author's right to security}

A foundation for the author's conception of a right to security could be grounded in 'natural' law theory, especially the concept of 'natural' rights. Some natural law theorists argue that rights are not created by governments but exist anterior to them and that governments are, in fact, created to secure these rights.

\section{Hobbesian 'absolutism'}

A particular feature of natural law theory has been the social-contract philosophy, a key exponent of which was Thomas Hobbes (1588-1679). Hobbes' most famous work was Leviathan which was first published in 1651 . Hobbes lived during a turbulent time in England's history - the rule of King Charles I, the Civil War and the Cromwellian Commonwealth - so he was greatly concerned at the evil of state collapse. He sought, therefore, to effect a strong central authority that maintained peace and order. If not, anarchy, which Hobbes described as a 'state of nature', would ensue - a place where only the strong would survive. ${ }^{39}$ Human life in the 'state of nature' would be 'solitary, poor, nasty, brutish, and short'. ${ }^{40}$ To avoid such horrors, individuals would come to organise themselves politically into a 'Commonwealth', entering into a tacit social contract - a bargain - between themselves, whereby they agreed to obey a sovereign chosen by the majority, in exchange for the sovereign providing them with security from the 'state of nature'. ${ }^{41}$ As a theoretical foundation for his collective human right the author finds such an approach to security particularly seductive. 
That said, Hobbes described the sovereign as a 'mortal God' 42 and literally described its power as 'absolute', ${ }^{43}$ suggesting a significant erosion of the rights of the individual. Indeed, when the commonwealth had chosen their sovereign, individuals' political power was at an end and they lost all rights except such as the government would find it expedient to grant. ${ }^{44}$ For the greater good of peace and order, Hobbes said that individuals had to accept 'some incommodity'. ${ }^{45}$ What might this 'incommodity' be? He believed that 'the greatest that in any form of government can possibly happen to people in general is scarce sensible, in respect of the miseries, and horrible calamities that accompany a Civil War'. ${ }^{46}$ So, for Hobbes, even the burdens of oppressive government were better than a complete chaos of the kind individuals suffer in war-torn contexts, for example, where social security, policing and law enforcement have broken down. But this approach seemingly ignores the reason(s) why we may be entertaining a right to security in the first place: to protect the very principles of democracy we are seeking to defend. Indeed, in condoning an oppressive government - assuming it continues to provide peace and order - Hobbes arguably failed to appreciate how the state itself might pose a threat to security. ${ }^{47}$ Thus, the Hobbesian model does not fully acknowledge how the modern state can simultaneously act as a guarantor of and $a$ threat to the security of individuals. ${ }^{48}$ And whilst we are facing a public emergency post $9 / 11$, or at the very least we were in 2001 , are we still in such a situation to which Hobbes was referring? That is, if we did not subscribe to the Hobbesian-style contract, would we be facing anarchy? Arguably, we would be less secure, at least collectively rather than individually, but it is safe to say that this would not result in a collapse of civil order? Finally, the author questions whether it is valid to 'trade-off' every human right of the individual, such as freedom from torture, in the cause of security. ${ }^{49}$ 
Notwithstanding these concerns, the author does not dismiss the 'absolutism' of Hobbes entirely, in formulating a theoretical basis for his collective human right to security. First, is the Hobbesian state a prime facie threat to security? For Hobbes the interests of the sovereign were largely the same as those of the commonwealth (or at least a majority of the commonwealth) so the sovereign seemingly would not use its powers injurious to the security interests of the commonwealth as a whole. ${ }^{50}$ The sovereign, like the individual, was motivated by self-interest: it wanted to retain the loyalty of its citizens. ${ }^{51}$ An oppressive regime that grossly stifled the liberty of its subjects could not hold their allegiance..$^{52}$ Thus, there were in fact limits to the sovereign's power. Indeed, the bargain between individuals was revocable: it was qualified and conditional on the sovereign providing effective security from the 'state of nature'. That is, when the state ceased to fulfil its duty of protection it had exceeded its authority and the individual no longer owed the state a duty of obedience: 'The obligation of subjects to the sovereign is understood to last as long, and no longer, than the power lasteth by which he is able to protect them. ${ }^{53}$ The gross violations of human rights committed in, say, the Soviet Union and Germany under the brutal authorities of Josef Stalin and Adolf Hitler respectively, in the 1930 s and 40 s, were classic examples where states themselves had become grave threats to security. And there have been more recent systematic human rights abuses by authorities in Rwanda in 1994, Bosnia in 1995 and Libya in 2011, as well as the ongoing situation in Syria. (For many of those affected by these abuses, a Hobbesian 'state of nature' was probably much more preferable to the fate that awaited them.) In failing, therefore, to honour the deal they have struck in providing protection, these countries have therefore delegitimised themselves, from a Hobbesian perspective, and revoked the duty of obedience, permitting the individual a 'right to resist'. Thus, the 'absolutism' 
of Hobbesian philosophy still has much to offer the author in constructing a theoretical justification for his right to security. That said, as with any political and constitutional theory this approach does of course have its limitations. The author in this piece is therefore developing a conceptual model which involves a modification of the Hobbesian position through the incorporation of aspects of liberalism, for example.

\section{Liberalism}

For Hobbes bad government was preferable to no government. Not so for John Locke (1632-1704) who was writing a generation after Hobbes. Locke's principal work, Two Treatises of Government, which was written between about 1679 and 1683, but not published until 1690, was a reaction to the allegedly tyrannical government of James II. In the Second Treatise Locke seemingly went further than Hobbes: Locke believed that the individual's obligation to obey the state, in return for protection, ceased in circumstances less demanding than a return to the state of nature. He justified such a position thus:

'To tell people they may provide for themselves by erecting a new legislative, when, by oppression, artifice, or being delivered over to a foreign power, their old one is gone, is only to tell them they may expect relief when it is too late, and the evil is past cure. This is, in effect, no more than to bid them first be slaves...and men can never be secure from tyranny if there be no means to escape it till they are perfectly under it. ${ }^{\prime} 54$ 
Furthermore, again in apparent opposition to Hobbes, Locke did view the 'absolute' power of the sovereign as a threat to the security of individuals. He therefore advocated a minimal state whose control was limited to its preservation and could not be used 'to destroy, enslave, or designedly to impoverish the subjects. ${ }^{55}$ With a significant reduction in the sovereign's control many more 'natural rights' of the individual eg 'life, liberty, and estate (property)' were guaranteed, which could not be removed without the individual's consent. ${ }^{56}$ Of these property was the most important, the protection of which was the chief reason for instituting government. ${ }^{57}$

The social contract theory of Locke was particularly prevalent in the $17^{\text {th }}$ and $18^{\text {th }}$ Centuries and influenced, say, the revolutions of America and France. For example, section 3 of the Virginia Declaration of Rights, 1776, expressly refers to the state's duty to provide security: 'That government is, or ought to be, instituted for the common benefit, protection, and security of the people, nation, or community...' But when the state is 'found [to be] inadequate [my italics]...a majority of the community has an indubitable, inalienable, and indefeasible right to reform, alter, or abolish it, in such manner as shall be judged most conducive to the public weal.' Thus, the individual's right of rebellion exists in circumstances less than a failure to by the state to protect people from a 'state of nature'. France's Declaration of the Rights of Man and of the Citizen, 1789, expresses similar values in Article 2: 'The aim of all political association is the preservation of the natural and imprescriptible rights of man. These rights are liberty, property, security, and resistance to oppression [my italics].' 
Liberal philosophy, as propounded by John Locke, is concerned about a right to security, as is the 'absolutism' of Thomas Hobbes. But Lockean liberalism is unwilling to surrender some fundamental, 'natural' rights such as liberty and rights to property for peace and order, because too much sacrifice by the individual is itself a threat to security. This conflicts with the opinions of the author, who is willing to sacrifice some 'natural' rights for the maintenance of peace and security (see more later). There is, therefore, an argument for some 'balance', however, between other freedoms of the individual, to do as they please, and society's need for protection against the harm that that person may commit, which some within contemporary liberalism, such as Jeremy Waldron have (reluctantly, it seems) acknowledged.

Waldron begins by echoing a classic liberal concern: whilst reducing liberty may prevent an action taking place which would otherwise pose a risk of harm, it necessarily also increases the power of the state, and there is a corresponding risk that this enhanced power may also be used to cause harm. ${ }^{58}$ And he says that the state is always looking to limit liberty, and a terrorist emergency provides a fine opportunity: 'People become more than usually deferential to the demands of their rulers in these circumstances and more than usually fearful that if they criticize the proposed adjustments they will be reproached for being insufficiently patriotic. ${ }^{59}$ However, Waldron does acknowledge that liberty cannot be comprehensive even under the most favourable circumstances 'nobody argues for anarchy' - and security has to be given some weight in determining how much liberty people should have. So there is always a balance to be struck. ${ }^{60}$ And that the balance is 'bound to change' as the threat to security becomes graver or more 
imminent. ${ }^{61}$ But he believes that the 'balancing rhetoric' needs to be subjected to 'careful scrutiny'. And calls for, say, evidence justifying greater security:

'If we do remain receptive to the need to compromise civil liberty, we must insist that those who talk the balancing-talk step up to the plate with some actual predictions about effectiveness. We should not give up our liberties, or anyone else's liberties, for the sake of purely symbolic gains in the war against terrorism.'62

Lucia Zedner is also cautious about embracing further security. She suggests that if security were an unqualified good, logically there could not be too much of it but there are several 'paradoxes' associated with it. ${ }^{63}$ For example, she argues that the expansion of security has enlarged, not diminished, the state: '...something akin to a security race ensures with both public and private competing...to offer security services. ${ }^{64}$ Next, Zedner claims that security promises reassurance but in fact increases anxiety: 'It is a deep irony that, by alerting citizens to risk and scattering the world with visible reminders of the threat of crime, it tends to increase subjective insecurity. ${ }^{65}$ Thirdly, she claims that security is posited as a universal good but presumes social exclusion. That is, there is a common tendency, both individual and collective, to overstate exposure to risk and hence to demand ever greater protections, thus making people more isolated. ${ }^{66}$ She claims that because the pursuit of security entails significant costs, security should be justified: 'Resort to security strategies should not be contemplated unless the potential harm is of sufficient gravity to justify the attendant costs of so doing. ${ }^{\prime 67}$ In a separate piece, Zedner specifically discusses the liberty/security trade-off, ${ }^{68}$ which she describes as 'perilous'. ${ }^{69}$ In a section titled 'What tips the balance?', she believes that all talk of 
rebalancing presupposes a prior imbalance, so those proposing reform must 'either identify a disequilibrium or externals factors that can be said to tip the balance out of kilter' ${ }^{70}$

The liberalism of Jeremy Waldron and Lucia Zedner seemingly acknowledge restrictions on individual liberty in the furtherance of public protection. But they oppose a sacrifice of freedoms of the individual for reasons of greater security without sufficient justification. For this author, however, this balance attaches insufficient weight to the ongoing threat of 'super-terrorism' from Islamist groups such as ISIL. The positives of enhanced state protection seem to have found a contemporary liberal voice in Loader and Walker's Civilizing Security. ${ }^{71}$ They devote whole chapters of their book to the 'good of security', ${ }^{72}$ 'the necessary virtue of the state' ${ }^{73}$ and 'security as a global public good'. ${ }^{74}$ They believe that security is a valuable public good - a 'thick public good'75- a constitutive ingredient of the good society, and that the democratic state has a necessary and virtuous role to play in the production of this good. ${ }^{76}$ But to release this potential the authors believe that security needs 'civilizing'. ${ }^{77}$ Why this is so is influenced significantly by traditional liberal concerns about the state:

'States - even those that claim with some justification to be 'liberal' or 'democratic' - have a capacity when self-consciously pursuing a condition called 'security' to act in a fashion injurious to it...They proceed in ways that trample over the basic liberties of citizens; that forge security for some groups while imposing illegitimate burdens of insecurity upon others, or that extend the coercive reach of the state - and security discourse - over social and political life. As monopoly 
holders of the means of legitimate physical and symbolic violence, modern states possess a built-in, paradoxical tendency to undermine the very liberties and security they are constituted to protect.' 78

Thus, for Loader and Walker, the state is a great civilizing force, a necessary component of the good society. But if it is to take on this role, they claim the state must itself be civilized - made safe by and for democracy. ${ }^{79}$

In conceiving a collective right to security, utilising 'positive' duties imposed on the state by established human rights, the author here is not entirely convinced by Hobbesian 'absolutism' on the one hand and liberalism - at least its Lockean traditions - on the other. So, thus far, he is attracted to the more 'pragmatic' (my words) theories of liberalism post $9 / 11$ echoed by Loader and Walker, which seem to draw the balance of security and rights much closer to the approach adopted by the author. But Loader and Walker's Civilising Security was published in 2007. This was six years after the 9/11 attacks in 2001, and two years after the 7/7 attacks in London in 2005. Perhaps in reconciliation of security with their defence of traditional liberal values there was some complacency creeping in? In recent years there has been the dramatic rise of ISIL, and its terror attacks, say, in mainland Europe: particularly in France and Belgium, close allies to the UK. These outrages serve only to remind states about the real and present terror threat they face. Bearing these concerns in mind, the author in the next section discusses another philosophy relevant to security, 'communitarianism'. This theory lends greater support to the author's conceptual foundation for his right to security than, say, Hobbesian 'absolutism', because, whilst it arguably draws on a model of security with, 
say, 'statist' traditions, especially since $9 / 11$, it does offer concessions to strands of liberalism.

\section{Communitarianism}

The author's theoretical justification for a right to security is a compromise between the social contract theories of 'state absolutism' on the one hand and liberalism on the other. Some liberals are maybe right to be concerned about an overly expansive interpretation of security, in that there is then much less emphasis on rights restraining the power of the state and more emphasis on augmenting the power of the state, with perhaps little evidence to support it. However, liberals arguably pay too much attention to individualism and too little attention to community. The author's right to security is borne out of 'positive' obligations imposed on the UK by virtue of, say, Article 2 of the ECHR, the right to life, for example, which would attach greater weight to the right of a 'group' or 'community' to security than the liberties of individuals. He aims to ground the foundations for a 'positive', 'collective' right to security in, say, 'communitarian' criticisms of liberalism. That is, whilst the preservation of some rights such as freedom from torture are still very important, rights in general need to be balanced much less in favour of the individual and balanced much more in favour of the community.

Recent theories of communitarianism are those advanced by, say, Amitai Etzioni ${ }^{80}$ and Mary Ann Glendon. ${ }^{81}$ For them, an important communitarian principle, which is particularly relevant to this piece, is redressing the balance between liberalism's emphasis on personal autonomy and social responsibilities. ${ }^{82}$ Unless society does so, it 
will continue to be self-centred and driven by self-interests. ${ }^{83}$ Indeed, they believe that the greatest danger for rights (and liberty more generally) arises when the social moorings of individuals are severed. ${ }^{84}$

The liberal emphasis on individualism - and neglect of social responsibilities - inherits much from Locke, but the former inherits much from, say, the American tradition of human rights and the US Declaration of Independence of the United States in particular. Rights Talk: The Impoverishment of Political Discourse by Mary Ann Glendon is especially important in this regard. In chapter two of her book, which is titled, 'The Illusion of Absoluteness', Glendon critiques the seeming absolute nature of American rights talk. ${ }^{85}$ She believes that this 'rhetoric of absoluteness' has the ill effect that it tends to downgrade rights into the mere expression of unbounded desires and wants: 'Excessively strong formulations express our most infantile instincts rather than our potential to be reasonable men and women. A country where we can do 'anything we want' is not a republic of free people attempting to order their lives together. ${ }^{86}$ And American rights talk, in its absoluteness, is silent on responsibilities: it seems to condone acceptance of the benefits of living in a democratic social welfare state, without accepting the corresponding personal civic obligations. ${ }^{87}$ On this issue, Etzioni notes, for example, that the majority of young people feel strongly that they have a right to demand a trial before a jury of their peers if charged with a crime; but many indicate that they would not rather serve on a jury. This is 'illogical' as well as being 'indecent and selfish', he believes. ${ }^{88}$ 
In conceiving his right to security this author believes that human rights are predicated on security - a view shared by Etzioni. For Etzioni the right to security is more fundamental than any others, so much so, 'it ought to be treated as a class unto itself' ${ }^{89}$ All other rights are contingent on the protection of life - whereas the right to security is not similarly contingent on any other rights. ${ }^{90}$ He declares:

'It sounds simplistic to state that dead people cannot exercise their rights, whereas those who are living securely at least have the possibility of exercising more rights in the future. However, it is still an essential truth: when and where the right to security is violated, all other rights are violated as well. ${ }^{91}$

So for communitarians like Etzioni security is a precondition for the enjoyment of rights and freedoms - a 'basic' right from which all others rights flow. And in reference to, say, security measures post $9 / 11$, he proclaims: 'True patriots...realize that one must protect the nation from all enemies and the essence of what it means to be patriotic is to protect our Constitution and its Bill of Rights with all our might...Only when we have failed to this will have done the terrorists' job for them. ${ }^{\prime 92}$

In a separate piece, Etzioni elaborates further on what states must do to protect themselves from terrorism. Seemingly sharing this author's belief in the significant curtailment of the rights of terror suspects for reasons of security, Etzioni criticises those who urge that suspected terrorists are to be treated like, say, other criminals; assumed innocent until proven guilty; tried in civil courts according to similar procedures employed in the trying of other criminals; afforded several layers of appeals if found 
guilty; and incarcerated and released once they have served their terms. Importantly, he suggests that such an approach accords 'terrorists more rights than they are entitled to, and unduly and significantly increases risks to the security of innocent citizens' ${ }^{93}$ Etzioni's explanation for why terrorists cannot be treated as ordinary criminals is that they need to be prevented rather than deterred: 'you cannot punish people who commit suicide after the fact. ${ }^{94}$

The author's 'positive', 'communitarian' right to security

The theme of this work is a positive, human right to security in the UK grounded in the state's obligations to protect life and prevent harm, as per, say, Articles 2(1) and 3 of the ECHR. And with a greater focus on the community rather than on either the individual or the state, this piece is further suggesting a positive, communitarian, right to security. If the author were to conceive his 'positive', 'communitarian' right to security as one in express terms, then a model for such a right could be Article 23(1) of ACHPR. And there is s.12(1) of the Constitution of the Republic of South Africa, 1996, referencing a right to security. This section includes the right not to be deprived of freedom arbitrarily or without just cause; not to be detained without trial; not to be tortured in any way; and not to be treated or punished in a cruel, inhuman or degrading way. But it also states that everyone has the right to free from all forms of violence from either public or private sources (my italics).

Conceiving, say, s.12(1) of the Constitution of the Republic of South Africa as a model for a right to security is not without its difficulties, however. Lazarus has written much about 
a right to security. Though not necessarily discussing s.12(1) in particular, the problems she identifies are still very pertinent. First, she believes that a right to security like this is simply too broad to be legally workable. ${ }^{95}$ Its apparent lack of sufficient certainty blurs the rights that flow from it, or even the correlative duties imposed on the state that might allow for such rights to be fulfilled. ${ }^{96}$ And since the right is connected to perceptions of future risk, she believes that there is no end to the kinds of risks that would have to be averted. ${ }^{97}$ Equally, it says nothing about how foreseeable the risks have to be in order to establish a breach of the right. ${ }^{98}$

Lazarus's objections do not end there: she is also concerned about 'duplication', in that the right to security does not seem to add anything to the other rights that are meant to be secured.${ }^{99}$ Such a right, she claims, should only protect that which other self-standing and established rights cannot, on their face, protect. Consequently, the 'right to security' should not encompass long established and self-standing rights such as the rights to life, liberty, freedom from torture and so on. ${ }^{100}$ She continues: politicians claim that the 'right to security' is a 'basic' or meta-right' on which all other rights are based. ${ }^{101}$ But this risks slipping from a right to security merely existing to affirm other rights, that is, a 'right to secure rights', to a belief which actively 'securitises' those rights. And in invoking security as a means to extend the 'state's coercive reach', we may end up 'righting security'. ${ }^{102}$ Lazarus therefore calls for the courts to stem the 'rhetoric of security' in a global environment of insecurity and ensure that the right does not become the catch-all justificatory foundation for a range of self-standing fundamental rights. ${ }^{103}$ 
In the face of these well considered criticisms, the author cannot ignore the obvious challenges of implementation of a right to security such as this. Indeed, even Etzioni expresses limits to security. He is not a Hobbesian 'absolutist': 'to seek full-fledged security, to obviate all threats, to end fear, puts us on the slippery slope at the bottom of which is a police state' ${ }^{104}$ He believes, therefore, that there must be restrictions on the power of the state. ${ }^{105}$ Indeed, one may recall the author's earlier acknowledgement that in fulfilling their duties to prevent terrorism, as per UN Security Council Resolution 2249 (2015), states must also respect their human rights obligations. Thus, in the following paragraphs the author suggests limits to his collective right to security.

First, who will have standing to enforce such a right? The author is expanding the interpretation of, say, the right to life beyond its traditional 'positive', protection of a specific individual, or individuals, but in so doing, he is relying on communitarian ideals as a theoretical model for doing so. If the author's right to security is to be justiciable, ${ }^{106}$ it is logical, perhaps, to draw on this theory's definition of 'community' to explain the 'standing' of those who can claim such a right. Etzioni, for example, describes 'community' as 'kin, friends, neighbours, and other community members', ${ }^{107}$ so the provenance of the group for the purposes of state protection would be relatively small. Thus, this author is not articulating an all embracing duty imposed on the UK authorities to protect everyone; there would have to be a 'communitarian' nexus between the individual making the claim and the threat that the state had allegedly failed to avert.

Communitarians are critical of, say, liberalism's overemphasis on rights but do not wish to qualify every right of the individual ${ }^{108}$ - an approach shared by this author. Thus, in 
'mapping' the author's right to security, it is important to look at the specific human right of the individual being curtailed for reasons of public protection, in that some rights are more important than others. First, there are those freedoms like Article 3 of the ECHR, the prohibition on torture, which in law, are 'absolute' and can never be infringed. (They are also 'non-derogable' in times of war or public emergency, as per, say, Article 15(2) of the ECHR.) Much as there may be pressing situations demanding the torture of a terror suspect for information, that is, in the so-called 'ticking bomb' situation, elsewhere, the author has rejected such a practice. ${ }^{109}$ (A presumption of guilt of a suspect and the reliability of the evidence gained though torture being obvious examples.) Thus, logically, here the author would exclude violating this freedom of the individual from the reach of his collective right to security.

Similarly, the right to life is ranked with freedom from torture in terms of its importance. Previously, this author has examined the killing of Jean Charles de Menezes by firearms officers of Britain's Metropolitan Police in 2005, for example. At the time de Menezes was suspected of being a suicide bomber, attempting to commemorate the suicide bombings in London on $7^{\text {th }}$ July. The author assessed the 'positive' duty to protect life, as per Article 2(1) of the ECHR, and the 'negative' right of the person who died, de Menezes, not be unlawfully killed, as per Article 2(2). ${ }^{110}$ In conclusion, accounting for the many features of Article 2, 'positive' and 'negative', the author found that the balance fell in favour of the state, that is, de Menezes was not unlawfully killed. Nonetheless, if in the event that the killing was later held to contravene Article 2, the author did believe, therefore, that insufficient weight would have been attached to the community's right to be protected from terrorism, especially suicide violence where the risks to life were that 
far greater. But in calling for a standard more beneficial to the public interest, the author neither called for a unilateral relaxation of existing terror laws in favour of state authorities nor an extension to them. ${ }^{111}$ Thus, whilst the author calls here for a more expansive interpretation of the UK's duty to protect life, as per Article 2(1), again, in mapping his right to security, he limits its reach to specific threats to public safety such as those involving suspected suicide bombers.

Moving away from basic liberties such as freedom from torture and the right to life in the 'hierarchy' of human rights, one 'finds' special rights - that is, those freedoms that can be infringed but only in limited circumstances - such as Article 5 of the ECHR, the right to liberty, and Article 6 of the ECHR, the right to a fair trial. Because these rights are seemingly less important than those discussed above, elsewhere the author has adopted a more expansive interpretation of 'positive' obligations justifying their curtailment, in supporting, for example, the UK's Terrorism Preventions and Investigation Measures ('TPIMs'). ${ }^{112}$ TPIMS, such as home residence requirements, are initiatives which are designed to disrupt the activities of terror suspects, whom the UK cannot prosecute because of insufficient evidence to satisfy a criminal trial. The TPIMS scheme extends the reach of state interference: arguably, a substantial control over the activities of a suspect violates the right to liberty, as per Article 5 of the ECHR; the imposition of an order merely on the civilian standard of proof, 'a balance of probabilities', violates the right to a fair trial, as per Article 6 of the ECHR; and the effects on the spouse and children of a suspect violate their right to private and family life, as per Article 8 of the ECHR. 


\section{Conclusion}

In $201478 \%$ of all deaths and 57\% of all attacks in 2014 occurred in just five countries: Afghanistan, Iraq, Nigeria, Pakistan and Syria. Europe, and the UK in particular, is relatively safe from terror attacks. Indeed, globally, at least 437,000 people are murdered each year, which is over the 13 times more than the number of victims of terrorism. ${ }^{113}$ That said, Bernard Hogan-Howe, the Chief Constable of the Metropolitan Police Service, Britain's most senior police officer, has said that recent terror atrocities in France will happen in the UK: they were a matter of 'when, not if'. ${ }^{114}$

Contributing to the debate about states' need to provide effective protection to their citizens from ISIL this piece has advocated a human right to security in the UK - but not the furtherance of the traditional liberal, right to security of the individual from the state: a collective, right of security from threats to public safety from non-state actors such as suspected terrorists. A foundation for such a human right are the 'positive' obligations imposed on European states to protect life, as per Article 2(1) of the ECHR, and prevent injury, as per Article 3 of the ECHR. Articles 1 and 13 of the ECHR are important considerations, too.

The social contract theories of Thomas Hobbes and John Locke emphasise the state's responsibility to provide security so serve - at least initially - as theoretical models for the author's conception of his 'positive' right to security. The author finds the lure of Hobbesian 'absolutism' particularly seductive, especially as he supports substantial inroads into the rights of the individual for the peace and order that would inevitably 
follow. However, in acquiring significant powers, Locke, for example, believed that the Hobbesian sovereign could itself pose a threat to security. The totalitarian regimes of, say, Stalin and Hitler were 'absolutist' ones seemingly supported by the writings of Hobbes, in that significant curtailments of human rights were justified on the basis of public protection, but these states were themselves a substantial threat to security. However, this is to do Hobbes an injustice: these states had in fact delegitimised themselves in the eyes of Hobbesian philosophy as the covenant upon which individuals had qualified their rights in exchange for protection was spectacularly broken. Thus, a right of rebellion to institute a new sovereign was permitted. That said, Locke believed that to legitimise a right of rebellion only when the state had gone too far - in enslaving its subjects, for example - was too late.

Moreover, in conceiving the Hobbesian model as the basis for public protection of democracy, the state seemingly undermines the very ideals it is seeking to preserve - is it doing the terrorists' job for them? And is there actual evidence that substantial gains in state power in the last 15 years or so, as the terror threat has continued, have actually made nations more safe? So liberal concerns about significant erosions of individual freedoms post $9 / 11$ should not be overlooked. ${ }^{115}$ Indeed, states must not ignore their human rights responsibilities in their efforts to counter terrorism.

Plotting a course through these models of state absolutism and liberalism one 'finds' communitarianism. In this piece, therefore, the author is advocating a 'positive' right to security grounded in the ideals of 'communitarianism' reflected in the writings of, say, Amitai Etzioni and Mary Ann Glendon. Etzioni and Glendon are critical of liberalism's 
Lockean traditions of absolute freedoms, in that they attach too much emphasis to rights and too little weight to responsibilities. Indeed, since 9/11, for example, Etzioni has emphasised the significance of security as a 'basic' right: to enjoy human rights requires security but not vice versa - a view shared by this author. But of equal significance Etzioni also warns against too much sacrifice of individual freedoms for reasons of public protection.

To make the author's 'positive', 'communitarian' right to security more legally workable, here he, too, suggests limits to its exercise. (Thus, the author still sees his right to security as primarily a justiciable one enforceable before the courts.) He does not advocate an all embracing duty imposed on the UK to protect everyone, justifying the broad erosion of individual liberties for the good of preventing terrorism: there would have to be a 'communitarian' nexus between the individual making the claim and the threat that the state had allegedly failed to avert. But in situations not involving the absolute rights of, say, a terror suspect, the author suggests that his 'communitarian' right to security should be accorded much greater weight in the liberty/security trade-off over, say, the rights to liberty and fair trial of the individual. Thus, initiatives in the UK such as TPIMS to prevent terrorism should not engage judicial scrutiny particularly intensively, when examining suspected violations of the rights of the individual.

* Senior Lecturer in Law, the University of Central Lancashire, Preston, UK. Email: idturner@uclan.ac.uk. Twitter: @DrlanTurner. The author is very grateful to Michael Salter, Amitai Etzioni and two anonymous referees for feedback on an earlier version of this article. The author is of course responsible for any errors or omissions.

${ }^{1}$ Michael Freeman, "Order, Rights and Threats: Terrorism and Global Justice," in Human Rights in the 'War on Terror', ed. Richard Ashby Wilson (Cambridge: Cambridge University Press, 2005), 38. 
2 Institute for Economics and Peace, Global Terrorism Index 2015 November 2015 http://economicsandpeace.org/wp-content/uploads/2015/11/Global-Terrorism-Index-2015.pdf (Accessed 2nd September 2016), at p2.

${ }^{3}$ Ibid.

${ }^{4}$ V. Dodd, "Europe Faces Highest Terror Threat Since 9/11, MPs Told" January 15, 2015. The Guardian https://www.theguardian.com/uk-news/2015/jan/13/europe-highest-terror-threat911-europol-fighting-overseas (Accessed August 31, 2016).

5 Rhonda Powell, "The Concept of Security," University of Oxford Socio-Legal Review, http://www.csls.ox.ac.uk/osIr/Papers/Entries/2012/6/21 Rhonda Powell files/Powell\%20\%282 012\%29\%20The\%20Concept\%20of\%20Security.pdf (accessed October 10, 2014).

${ }^{6}$ Piet Hein van Kempen, "Four Concepts of Security - A Human Rights Perspective," Human Rights Law Review 13, no.1 (2013): 1.

7 Ibid.

${ }^{8}$ Article 9(1) of the ICCPR also discusses the 'procedural' elements of the right: 'No one shall be deprived of his liberty except on such grounds and in accordance with such procedure as are established by law.' What these 'procedural' rights are, are stated in Articles 9(2)-9(4); these include knowing the grounds for a detention by the state and the charges against a person, being brought promptly before a judge and being entitled to trial within a reasonable time or to release.

${ }^{9}$ Regionally, there is also, say, Article 7(1) American Convention on Human Rights (ACHR), which states: 'Every person has the right to personal liberty and security' and Article 6 of the African Charter on Human and Peoples' Rights (ACHPR) states: 'Every individual shall have the right to liberty and to the security of his person.'

${ }^{10}$ See, for example: Javaid Rehman, International Human Rights Law (London: Pearson, 2010), 200-203; and Bantekas, Ilias and Oette, Lutz. International Human Rights Law and Practice (Cambridge: Cambridge University Press, 2013), 338-345.

11 (1973) 3 EHRR 76.

12 lbid., at p.89. But the ECtHR in the later case of Kurt v. Turkey (1998) 27 EHRR 373 did give a more expansive interpretation of Article 5(1) of the ECHR, beyond the traditional liberal idea of arbitrary detention of the individual. The case concerned the disappearance of a Turkish citizen after his arrest by Turkish authorities. Requests by his family for information and an investigation as to his whereabouts were unsuccessful. In concluding that there had been a breach of the right to security of the person the ECtHR said: 'What is at stake is both the protection of the physical liberty of individuals as well as their personal security in a context which, in the absence of safeguards, could result in a subversion of the rule of law and place detainees beyond the reach of the most rudimentary forms of legal protection.' [123]. But the duties imposed on the Turkish authorities did not stop there: the court said that having assumed control over an individual it was incumbent on the authorities to account for their whereabouts: 'For this reason, Article 5 must be seen as requiring the authorities to take effective measures to safeguard against the risk of disappearance and to conduct a prompt effective investigation into an arguable claim that a person has been taken into custody and has not been seen since.' [124]

${ }^{13}$ But, according to Article 4(2) of the ICCPR, some fundamental rights such as freedom from torture, as per Article 7 of the ICCPR, and freedom from slavery, as per Article 8(1) of the ICCPR, can never be suspended. And note Article 15(2) of the ECHR: 'No derogation from Article 2, except in respect of deaths resulting from lawful acts of war, or from Articles 3, 4 (paragraph 1) and 7 shall be made under this provision.'

${ }^{14}$ Unlike its companion agreement, the ICCPR, the ICESCR is more of a 'promotional' convention. This is because it is not intended for immediate implementation; the state parties, as per Article 2 , having agreed only to take steps toward 'achieving progressively the full realization of the 
rights recognized in the...Covenant' and then subject to 'the maximum of [their] available resources'.

${ }^{15}$ To monitor compliance with these obligations, the Charter has created an executive body, the UN Security Council (UNSC), which is in permanent session at UN headquarters in New York. Article 24(1) of the Charter confers primary responsibility for the maintenance of international peace and security on the UNSC. This is not merely an ideal or aspiration but a rule backed up by sanctions. For example, in disputes between nations of the UN, which threaten international peace and security, the Security Council may authorise, say, economic or diplomatic sanctions, as per Article 41 of the Charter, or the use of military action, as per Article 42.

${ }^{16}$ Article 48 of Protocol I states that Parties to a conflict shall at all times distinguish between the civilian population and combatants and between civilian and military objectives and, accordingly, shall direct their operations only against military ones. Thus, citizens shall not be the object of attack, as per Article 51(2). States are duty-bound, legally, to take all feasible precautions in choosing weapons and methods of warfare which avoid incidental loss of life, injury to civilians and damage to civilian objects such as homes, schools, hospitals and places of worship, as per Article 52. State parties to the Protocol (and the four Geneva Conventions) are under an express obligation to search for suspected offenders, regardless of their nationality and of the place of the offence, and either bring them before their own courts or hand them over to another party for trial. In international law this principle is known as 'universal jurisdiction'.

17 Hitoshi Nasu, "The Place of Human Security in Collective Security," Journal of Conflict and Security Law 18, no.1 (2013): 97.

${ }^{18}$ Paragraph 143 of the Resolution states: 'We stress the right of people to live in freedom and dignity, free from poverty and despair. We recognize that all individuals, in particular vulnerable people, are entitled to freedom from fear and freedom from want, with an equal opportunity to enjoy all their rights and fully develop their human potential.' UN General Assembly, "2005 World Summit Outcome," see: http://www.un.org/en/ga/search/view doc.asp?symbol=A/RES/60/1 (accessed March 12, 2015). In 2012 the UN General Assembly expanded on its earlier human security resolution - see: - UN General Assembly, "Follow-up to paragraph 143 on human security of the 2005 World Summit Outcome," $\quad$ http://www.un.org/en/ga/search/view doc.asp?symbol=\%20A/RES/66/290 (accessed March 12, 2015).

${ }^{19} \mathrm{Nasu}$, op.cit., at p.99.

20 Ibid., Nasu also introduces another approach to human security: 'freedom from want', encompassing a wide range of security issues such as economic security, energy security and environmental security. But he says: '[An] expanded conception of human security [has] been subjected to criticism that [this] is all-encompassing with an endless list of security issues, making the notion too ambiguous to be of any use for policy-making.' (at p.100) For those who advocate a more expansive approach to security such as access to resources, water or health, see, for example: Sandra Fredman, "The Positive Right to Security," in Security and Human Rights, ed. Benjamin J. Goold and Liora Lazarus (Oxford: Hart Publishing, 2007), 307-324. ${ }^{21}$ Ibid.

22 UN General Assembly, "2005 World Summit Outcome," http://www.un.org/en/ga/search/view doc.asp?symbol=A/RES/60/1 (accessed March 12, 2015). ${ }^{23}$ UNA-UK, "R2P - in Detail" http://www.una.org.uk/content/r2p-detail (Accessed March 11, 2015).

${ }^{24} \mathrm{CCPR} / \mathrm{C} / 75 / \mathrm{D} / 916 / 2000$.

25 [7.2]. Sri Lanka was also in violation of Article 9(1) by failing to investigate the complaints of the claimant about the death threats he had received [7.3].

${ }^{26}$ MC v. Bulgaria (2005) 40 EHRR 20.

${ }^{27}$ Siliadin v. France (2006) 43 EHRR 15. 
${ }^{28}$ Rantsev v. Cyprus and Russia (2010) 51 EHRR 1.

${ }^{29}$ Storck v. Germany (2006) 43 EHRR 6.

${ }^{30} X$ and $Y$ v. Netherlands (1985) 8 EHRR 235.

${ }^{31}$ See, for example, Osman v. United Kingdom (1998) 29 EHRR 245.

32 Dimitros Xenos, The Positive Obligations of the State Under the European Convention of Human Rights (London: Routledge, 2012), 11.

${ }^{33}$ Ibid., at p. 21.

${ }^{34}$ Powell is correct, therefore, when she claims: 'Given the duty to secure all rights in Article 1, it seems unnecessary to specifically mention security [in Article 5] at all.' See: Rhonda Powell, "The Right to Security of Person in European Court of Human Rights Jurisprudence," European Human Rights Law Review 6 (2007): 661.

${ }^{35}$ Liora Lazarus, "Mapping the Right to Security' in Security and Human Rights, ed. Benjamin J. Goold and Liora Lazarus (Oxford: Hart Publishing, 2007): 336.

${ }^{36}$ Ibid., at p.327.

37 Andrew Parker, Terrorism, Technology and Accountability. January 8, 2015. https://www.mi5.gov.uk/news/director-general-speaks-on-terrorism-technology-and-oversight (Accessed September 2, 2016), at para 21.

${ }^{38}$ Malcolm Evans, "Torture," European Human Rights Law Review 5 (2006): 104.

39 Thomas Hobbes, "Leviathan or the Matter, Forme, \& Power of a Common-wealth Ecclesiasticall and Civill 1651," http://socserv2.socsci.mcmaster.ca/econ/ugcm/3\|l3/hobbes/Leviathan.pdf, Chapter XIII (accessed September 12, 2014)

${ }^{40} \mathrm{lbid}$.

${ }^{41}$ Ibid., Chapter XIV, at p.82.

${ }^{42}$ Richard Tuck, Hobbes (Oxford: Oxford University Press, 1989): 80.

${ }^{43}$ Thomas Hobbes, op.cit., Chapter XVII, at pp.105-106.

${ }^{44}$ Bertrand Russell, History of Western Philosophy (London: George Allen and Unwin, 1961): 535.

${ }^{45}$ Thomas Hobbes, op.cit., Chapter XVIII, at p.113.

${ }^{46} \mathrm{lbid}$.

${ }^{47}$ Liora Lazarus, "The Right to Security," in The Philosophical Foundations of Human Rights, eds, Rowan Cruft, Matthew Liao and Massimo Renzo (Oxford: Oxford University Press, 2014), 3.

${ }^{48}$ Loader, lan and Walker, Neil. Civilizing Security (Cambridge: Cambridge University Press, 2007), 11.

${ }^{49}$ On this issue, see, for example: Ian Turner, "Human Rights and Anti-Terrorism: A Positive Legal Duty to Infringe Freedom from Torture," Studies in Conflict and Terrorism 35 (2012): 760-778; and Ian Turner, "Freedom from Torture in the 'War on Terror': is it Absolute?" Terrorism and Political Violence 23, no.3 (2011): 419-437.

${ }^{50}$ Richard Tuck, op.cit., at pp.77-78.

${ }^{51}$ Thomas R. Pope, Social Contract Theory in American Jurisprudence: Too Much Liberty and Too Much Authority (New York: Routledge, 2013): 5.

52 Ibid.

${ }^{53}$ Thomas Hobbes, op.cit., Chapter XXI, at p.136.

${ }^{54}$ John Locke, Two Treatises of Government In the Former, The False Principles and Foundation of Sir Robert Filmer, and His Followers, Are Detected and Overthrown: The Latter, Is an Essay Concerning the Original, Extent, and End, of Civil Government http://socserv2.socsci.mcmaster.ca/econ/ugcm/3\|l3/locke/government.pdf accessed 10 October 2014 (accessed October 10, 2014). The state of nature, for Locke, was much less bleak than that envisaged by Hobbes - see: John Dunn, Locke (Oxford: Oxford University Press, 1984): 53

${ }^{55}$ Ibid., at p.163. 
${ }^{56}$ Bertrand Russell, op.cit., at p.604. But what happens if the removal of an individual's property without their consent was conducive to, say, the well-being of the majority, such as taxation to fund war for reasons of security? Russell argues that Locke did not adequately address this obvious contradiction (at p.609).

57 lbid.

58 Jeremy Waldron, "Security and Liberty: The Image of Balance," Journal of Political Philosophy 11, no.2 (2003): 205.

${ }^{59}$ Ibid., at p.191.

${ }^{60}$ Ibid., at p.192.

${ }^{61} \mathrm{lbid}$.

62 Ibid.

${ }^{63}$ Lucia Zedner, "Too Much Security?" Journal of Sociology of Law 31, (2003): 157.

${ }^{64} \mathrm{lbid}$., at p.162.

65 Ibid., at p.163.

${ }^{66}$ Ibid., at p.166.

${ }^{67}$ Ibid., at pp.174-175.

68 Lucia Zedner, "Securing Liberty in the Face of Terror: Reflections from Criminal Justice," Journal of Law and Society 32, no.4 (2004): 507-533.

${ }^{69} \mathrm{lbid}$., at p.509.

${ }^{70}$ Ibid., at p.511.

${ }^{71}$ Ian Loader and Neil Walker, op.cit.

${ }^{72}$ Chapter 6, pp.143-169.

${ }^{73}$ Chapter 7, pp.170-194.

${ }^{74}$ Chapter 9, pp.234-264.

${ }^{75}$ Ibid., at p.4

${ }^{76}$ Ibid., at p.5.

77 Ibid., at p.4.

78 lbid., at p.7.

79 lbid.

${ }^{80}$ Amitai Etzioni, The Spirit of Community: The Reinvention of American Society (New York: Touchstone, 1994); Amitai Etzioni, The New Golden Rule: Community and Morality in a Democratic Society (New York: Basic Books, 1996); Amitai Etzioni (ed), The Essential Communitarian Reader (Lanham: MD, Rowman and Littlefield Publishers, 1998). In the main text the author says 'recent' communitarians to distinguish them from, say, earlier ones, such as Alasdair Maclntyre and Michael J Sandel. See, for example, Alasdair Maclntyre, After Virtue: A Study in Moral Theory (Notre Dame: University of Notre Dame Press, 1981); and Michael J Sandel, Liberalism and the Limits of Justice (Cambridge: Cambridge University Press, 1982). Indeed, Maclntyre in a later edition, After Virtue (Bloomsbury Revelations) (London: Bloomsbury, 2013), expressed unease with the label 'communitarianism'. In the Prologue he says: 'I see no value in community as such - many types of community are nastily oppressive - and the values of community, as understood by the American spokespersons of contemporary communitarianism, such as Amitai Etzioni, are compatible with an supportive of the values of the liberalism that I reject.'

${ }^{81}$ Mary Ann Glendon, Rights Talk: The Impoverishment of Political Discourse (New York: Free Press, 1991); Mary Ann Glendon, "Rights in Twentieth Century Constitutions," in Rights and the Common Good: The Communitarian Perspective, ed, Amitai Etzioni (New York: St Martin's Press, 1995), 27-36.

82 Ibid., at iii. 
${ }^{83}$ Amitai Etzioni, "Old Chestnuts and New Spurs," in New Communitarian Thinking: Persons, Virtues, Institutions and Communities, ed, Amitai Etzioni (Charlottesville: University of Virginia Press, 1995), 22

84 Ibid.

${ }^{85}$ Op.cit, 18-46.

$86 \mathrm{lbid}$.

${ }^{87} \mathrm{Ibid}$. at p.14.

${ }^{88}$ Amital Etzioni, "Too Many Rights, Too Few Responsibilities," in Towards a Global Civil Society, ed, Michael Walzer (New York: Berghahn Books, 1995), 96.

${ }^{89}$ Amitai Etzioni, Security First: For a Muscular, Moral Foreign Policy (New Haven: Yale University Press, 2007), 1.

${ }^{90} \mathrm{Ibid}$., at p.6.

${ }^{91} \mathrm{lbid}$. That said, it may be possible to exercise rights in conditions of insecurity - see, for example, Jeremey Waldron, Torture, Terror and Trade-Offs: Philosophy for the White House (Oxford: Oxford University Press, 2010): 177.

${ }^{92}$ Amitai Etzioni, How Patriotic is the Patriot Act? Freedom Versus Security in the Age of Terrorism (New York: Routledge, 2005), 1-3.

${ }^{93}$ Amitai Etzioni, "A Liberal Communitarian Paradigm for Counterterrorism," Stanford Journal of International Law 49, no.2 (2013): 347.

${ }^{94}$ After very kindly responding to some questions about communitarianism posed by the author, Amitai Etzioni wished to explain this point. (Email to the author, dated $28^{\text {th }}$ July 2016).

${ }^{95}$ Liora Lazarus, op.cit. (2014), at p.10.

${ }^{96}$ Liora Lazarus, "The Right to Security - Securing Rights or Securitising Rights," in Examining Critical Perspectives on Human Rights, ed, Robert Dickinson (Cambridge: Cambridge University Press, 2012), 100-101.

${ }^{97}$ Liora Lazarus, op.cit. (2014), at p.10.

98 Ibid.

${ }^{99}$ Liora Lazarus, op.cit. (2012), at pp.100-101.

100 Liora Lazarus, op.cit. (2007), at p.327.

101 Ibid., at p.98.

102 Ibid., at p.103.

103 Liora Lazarus, op.cit. (2007), at p.344.

${ }^{104}$ Amitai Etzioni, op.cit. (2007), at p.2

105 Ibid., at pp.358-359. For example, they should be captured rather than killed; they should not be tortured or turned over to other states that are likely to kill or torture them. Rather than holding them indefinitely, they should be subject to a defined period of administrative detention, which could be extended through legally established channels if necessary.

${ }^{106}$ To be honest, the author has no strong opinions on the issue of enforceability, so is prepared to accept a non-justiciable right to security along the lines of the ' $\mathrm{R} 2 \mathrm{P}$ ' concept, which relies on political and institutional pressure for its enforcement rather than through legal redress. That said, a call in the main text for a more expansive interpretation of 'positive obligations' through existing human rights that are legally enforceable does suggest a commitment to a right to security that is justiciable.

107 Amitai Etzioni, "Preface: We, the Communitarians", in Rights and the Common Good: The Communitarian Perspective, ed, Amitai Etzioni (New York: St Martin's Press, 1995), iv.

108 Amitai Etzioni, "The Responsive Communitarian Platform: Rights and Responsibilities," in Rights and the Common Good: The Communitarian Perspective, ed, Amitai Etzioni (New York: St Martin's Press, 1995), 19.

${ }^{109}$ Ian Turner, op.cit. (2012) and op.cit. (2011). 
110 Ian Turner, "Suicide Terrorism, Article 2 of the ECHR and the Shooting of Jean Charles de Menezes" Web Journal of Current Legal Issues 4 (2008) http://www.bailii.org/uk/other/journals/WebJCLI/2008/issue4/turner4.html (accessed October 30, 2014); see also, lan Turner, "Article 2 of the ECHR, the Investigative Obligation and the Shooting of Jean Charles de Menezes" Web Journal of Current Legal Issues 5 (2009) http://www.bailii.org/uk/other/journals/WebJCLI/2009/issue5/turner5.html (accessed October 30, 2014).

${ }^{111}$ Ibid., at pp.26-27.

112 Ian Turner, "The Prevention of Terrorism: in Support of Control Orders, and Beyond," Northern Ireland Legal Quarterly 62, no.3 (2011): 335-359.

113 Ibid.

${ }^{114}$ Samuel Osborne, 'UK Terror Attack is a Matter of 'When, not If', Met Chief Warns' July 31, 2016 The Independent. http://www.independent.co.uk/news/uk/home-news/uk-terror-threatattack-chance-risk-security-isis-london-met-police-a7164756.html (Accessed September 2nd, 2016).

${ }^{115}$ Perhaps, therefore, to work through this apparent ideological 'impasse', the author should be advocating a freedom from insecurity, to reflect traditional, liberal sensibilities, rather than a right to security? But this would still require intervention by the state for the right to be fulfilled, it being ostensibly a 'positive' right in the sense of, say, Article 6 of the ECHR, the right to a fair trial by an independent and impartial court or tribunal. 